\title{
Dynamics of the Syrian Civil War and Its Impact on Vulnerable Civilians
} Shaba Sampson ${ }^{1 *}$

${ }^{1}$ (Ph.D), Associate Professor and Lecturer in the Department of Public Law, Federal University Oye-Ekiti, Ekiti State Nigeria

\author{
DOI: $10.36348 /$ sijlcj.2021.v04i04.002 \\ | Received: 27.02.2021 | Accepted: 03.04.2021 | Published: 13.04.2021 \\ *Corresponding author: Shaba Sampson
}

\section{Abstract}

Not a few governments of the countries in the Middle East have had their share of woes from pro-democracy movements, commonly known as the Arab Spring - a short hand for series of uprisings that has toppled long-held political regimes. While some of them were peaceful and civil in countries like Tunisia and Egypt, the story is not the same in the case of Syria, Yemen, Bahrain, Libya, et cetera. This paper assesses the decade long civil war in Syria and its effect on civilian victims especially the vulnerable groups amongst them. From civil protests and demonstrations; to political concessions by government (which were bluffed); and the eventual clamp down on protesters by the regime. As is common to such protests in other Arab nations, the violent military response by the Assad regime radically militarized the hitherto peaceful protesters with the sad consequence of a full blown civil war in 2011. As yet, there is no committed peace effort either at the international or regional levels. Foreign involvements in the Syrian war have fundamentally changed its dynamics. It has sharply perforated the loose bond that had existed and shred Syria along ethnic, religious and sectarian lines with each engaged in a war of attrition for survival using their different armed militias. At the receiving end are civilians whose life-support facilities are directly targeted and destroyed; are being sexually assaulted; abducted and killed and in dire humanitarian situation as a result of mass displacements.

Keywords: Armed conflict, attacks, abductions, crime, militia, violence.

Copyright (C) 2021 The Author(s): This is an open-access article distributed under the terms of the Creative Commons Attribution 4.0 International License (CC BY-NC 4.0) which permits unrestricted use, distribution, and reproduction in any medium for non-commercial use provided the original author and source are credited.

\section{INTRODUCTION}

Arguably, the armed conflict in Syria is within the threshold of a non-international armed conflict. Albeit, it has been argued that the conflict in Syria has acquired a transnational character, nevertheless the conduct of the parties involved must of necessity conform to extant rules of international law [1]. In a thumbnail, skirmishes of protests and demonstrations that snowballed into the armed conflict in Syria began about March in 2011 [2]. From in and around Damascus, the peaceful protests spread to the Southern city of Dara [3]. At initial stage, the demands of the protesters were limited to the release of political

\footnotetext{
${ }^{1}$ Factors such as intensity, organization/command structure, control of a part of the territory and conduct of conflict in accordance with the law of war.

${ }^{2} \mathrm{~L}$ Arimatsu and M Choudhury, 'The Legal Classification of the Armed Conflicts in Syria, Yemen and Libya,' 6. Available at: <www.ohchr.org/....> Accessed on 4/12/2020.

${ }^{3}$ Ibid.
}

prisoners and the reform of the Assad regime. Regime overthrow was not part of the agitation at the beginning.

Despite the peaceful nature of these demonstrations and protests, the Government of Syria, headed by President Bashar al-Assad, instead of engaging protesters civilly and constructively, decided to crackdown on protesters. Armed Government forces with affiliate security forces, civilian police and the Alawites' [4] civilian militia (or shabbiha) were all deployed against armless civilians who were simply exercising their right under the law to protest against repressive policies of the government [5]. Excessive use of force in the succeeding days, especially the use of lethal weapon on the demonstrators resulted in the

\footnotetext{
${ }^{4}$ They are mystical Shiite Islamic group, raised in the Alawite culture that holds Ali ibn Talib in high reverence and staunch supporters of President Assad's regime.

${ }^{5}$ It is a fundamental right inherent in man and enshrined in international, regional and national human rights instruments.
} 
Shaba Sampson., Sch Int J Law Crime Justice, Apr, 2021; 4(4): 198-204

deaths of many civilians and several others were arrested, tortured and humiliated [6].

Like wild fire, the demonstrations spread to other parts of Syria with more people joining as the days went by. This development compelled Bashar alAssad to make conciliatory offers such as the release of political prisoners; the lifting of several years of state of emergency, among others [7]. Demonstrations continued despite these concessions by the government and later became violent and marred their initial peaceful character. By the end of April 2011, large scale military operations had been launched by the army in collaboration with other security forces leading to colossal loss of lives among civilians [8].

As the crackdown on civilians went on, a growing displeased number of military personnel and that of other security agencies became discontent with government's use of lethal weapon against civilians. Within June and July, 2011 a handful of these displeased elements had defected and announced the formation of the Free Syrian Army [9] (herein FSA). As is always the case with internal conflicts, this move introduced a dangerous and complicated dimension to the conflict. Able bodied civilians suddenly realized that, as a sign of patriotism to either the government or group interest, it was no longer golden to be aloof, but be involved one way or the other in the conflict that was already destroying the political permutations and the very fabrics of Syria such as the loose and the inherently fragile bond that had existed between the rich and the poor; the ruling aristocratic class and the ruled; the divergent religious, sectarian, ethnic and social interests. Unlike his father and predecessor who was able to manage the situation, Assad's sheer lack of indepth knowledge about the fragile political union that had existed among the various groups in Syria and how to cleverly sustain this bond between these interests, though variegated as wont his father, became his Achilles' heel.

Operations by the Free Syrian Army were coordinated by one of the defectors, Col. Riad al-Assad with his Command Headquarters located in Turkey. Some of the defectors formed localized armed groups

\footnotetext{
${ }^{6}$ Arimatsu and Choudhury, (n3) 6. see E Ferris, etal, Syrian Crisis: Massive Displacement, Dire Needs and a Shortage of Solution, (September 18 2013), Brookings Project on Internal Displacement 5. Available at: <www.brooklings.edu/...syria.../syrian...> Accessed on 9/7/2019.

${ }^{7}$ Ibid.

${ }^{8}$ E A Abdel Salam, 'The Arab spring: Its origins, evolution and consequences... four years on' [2015] (23:1) Intellectual Discourse, 124.

${ }^{9}$ Arimatsu and Choudhury, (n3), 9.
}

and civilians joined their ranks to take up arms against government forces [10].

In August 2011, opposition activists met in Istanbul, Turkey and formed a political umbrella body known as the Syrian National Council [11] (herein SNC) under which all opposition groups were expected to operate. Consequently, in January 2012, the FSA and the SNC reached an agreement on strategies and intelligence in order to improve co-ordination of their operations [12]. With this level of organization and sustained intensity in armed confrontations against the regime and its allied groups, and coupled with the direct and indirect foreign involvements, it soon became very clear that the opposition now seeks an outright overthrow of Assad's autocratic regime in favour of a populist and democratically elected government [13].

Now in its $10^{\text {th }}$ year, the Syria crisis had been characterized by the negative record of wanton destruction of lives and properties with no end in sight. Several peace meetings between the warring parties have been convened at different locations and time [14] but each of them collapsed owing to disagreements especially on the fate of Assad [15], which itself is an overt display of hypocrisy on the part of the international community and its peace envoys. Khan aptly summarizes the despondent situation of the Syrian people as the war rages in the following word; "the worst sufferers are the Syrian people who neither have any supporters nor any helpers. All they have is misery, death, hunger and hopelessness" [16]. It is disgustingly disappointing, especially in a $21^{\text {st }}$ century world where everything that is capable of engaging human enterprise including armed conflict, have become subject of regulations through legal framework.

\section{DYNAMICS OF THE SYRIAN WAR}

Having lasted for a decade, the dynamics of the conflict in Syria has since changed and is now predominantly religious, sectarian and ethnic in nature coupled with foreign involvements base on political interests rather than genuine and committed efforts for

\footnotetext{
${ }^{10}$ Ibid.

${ }^{11}$ Ibid, 10. The Syrian National Council otherwise known as Syrian National Transitional Council or the National Council of Syria is a Syrian opposition coalition based in Instabul Turkey formed in August 2011.

${ }^{12}$ Ibid.

${ }^{13} \mathrm{R}$ M Khouri, 'The Implications of the Syrian War for New Regional Orders in the Middle East' MENARA Working Papers No. 12, September 20185.

${ }^{14} \mathrm{H}$ U Khan and W Khan, 'Syria: History, The Civil War and Peace Prospects', [Issue - 2, 2017] (24) Journal of Political Studies, 599.

${ }^{15}$ Ibid.

${ }^{16} \mathrm{Ibid}, 596$.
} 
Shaba Sampson., Sch Int J Law Crime Justice, Apr, 2021; 4(4): 198-204

the restoration of peace and order in Syria. Reactions by the parties in the conflict to these involvements heightened the intensity of attacks with the sad consequences of larger scale of casualties and displacements among civilians. Armed Parties have thrown caution and professionalism to the wind in their conducts as they become more radicalized and extremely militarized than they have ever been [17].

Closely related to this is the proliferation of armed groups and militias for and against the regime of Assad. On one hand, the divergent political interests, religious beliefs, sectarian ideologies, social class structure, ethnic loyalty accentuated by the respective interests of foreign and regional powers have worsened the fragile political bond in Syria. On the other hand, the United Nations Organization which prides its foundation on the precepts of world peace, security and order has woefully failed to live up to expectation, a disappointment to the entire global family.

On occasions, draft UNSC's resolution under Chapter VII of the UN Charter calling for drastic measure on Assad's regime met brick walls from Russia and China because of their selfish political, economic and military interests. Sadly, an overwhelmed United States of America is increasingly becoming less visible in the peace process for the war-turned Syria. It is not clear the fate the future holds for the UNO given its selective treatment on issues of international and regional peace, order and security which Syria happens to be one bad example of its disappointing posture.

However, in its assessment of the level of impunity and atrocious acts against civilians by the parties to the conflict in Syria, the United Nations Human Rights Council's Independent International Commission of Inquiry on the Syrian (herein COI) Arab Republic found that:

Government forces and affiliated militia have committed murder, torture, rape, forceful displacement, enforced disappearance and other inhuman acts. Many of these crimes were perpetrated as part of widespread or systematic attack against civilian populations.... [18].

As concerning anti-government armed groups, the Commission of Inquiry stated:

Anti-government armed groups have also committed war crimes, including murder, sentencing and execution without due process, torture, hostage taking and pillage.... [19].

\footnotetext{
${ }^{17}$ Ferris, etal, (n6) 9.

${ }^{18}$ UN Human Rights Council, Report of the IICoI on the Syrian Arab Republic, A/HRC/23/58, 4 June 2013, summary, 1. Cited in Ferris, (n6) 7. ${ }^{19}$ Ibid.
}

As ethnic and sectarian hatred between the parties and their allies deepens, the security situation in Syria slides into a morbid anarchy resulting in high apprehension and casualty level with attendant acute humanitarian crisis while the world simply watches on. Syria is in rubbles and its people in total despondency, no body outside Syria is sincerely interested in its revival and restoration. It is only Syrians themselves that can bring peace, hope and a future to Syria. Not until they are ready to forget their differences and see each other in the true spirit of brotherhood; mutually negotiate and agree on a peace process based on terms that suit their peculiarities, there can never be true healing which only can herald genuine peace. A Tunisian poet, Abu al-Qasim al-Shabi aptly and graphically describes the idea of a peace initiative by the victims themselves thus:

If, one day, a people desire to live, then fate will answer their call. And their night will then begin to fade, and their chains break and fall. For he who is not embraced by a passion for life will dissipate into thin air. At least that is what all creation has told me, and what its hidden spirits declare [20].

\section{VIOLATIONS AGAINST CIVILIANS Attacks on Civilians}

Up until July, 2011 demonstrations and protests in Assad Syria remained peaceful. However, following the formation of a formal opposition group the FSA and a change in the motive of the opposition, the pattern of attacks, especially by government forces became indiscriminate particularly against civilians and civilian infrastructure contrary to article 3 common to the four Geneva Conventions [21] and Additional Protocol II [22] to the Geneva Conventions. Direct targeting of civilians and civilian infrastructures are considered gross violations of Geneva Law and punishable under international law [23].

Attacks on civilian population in Syria have been widespread and systematic resulting in the death of hundreds of civilians. Figures about deaths in Syria can never be accurate for want of adequate or total absence of information about several locations where these deaths took place.

\footnotetext{
${ }^{20}$ E H Aissa, 'The Arab Spring: Causes, Consequences, and Implications' available at: <www.researchgate.net > ... > Political Science, Arab Spring $>$ Accessed on $1 / 3 / 2021$.

${ }^{21}$ Geneva Conventions of 12 August 1949, Common article 3 paragraph 1 .

${ }^{22}$ AP II, article 13.

${ }^{23}$ See Statute of the ICC Article (8) (2) (i) and (ii) and the case of Prosecutor v. Blaskic, IT-95- 14-T(3 March 2000)
} 
Shaba Sampson., Sch Int J Law Crime Justice, Apr, 2021; 4(4): 198-204

Escalation of violence and direct targeting of civilians crescendoed in the cities of Da'ra, Bariyas, Homs, Ar Rastan and the suburbs of Damascus with lots of atrocities [24]. Several deaths were reported in the cities of Homs, Dara, Hama, Dayr Az Zawr and Rif, as Government forces always targeted public assemblies and even funeral processions. By February 2013, recorded civilian deaths had hit a whooping, (though inaccurate) figure of 60,000 [25] with several other deaths unknown.

Rebel groups are also active accomplices in these senseless and dastardly acts against civilians and civilian infrastructures and facilities, especially and initially too, in the cities of Aleppo and Damascus which the opposition sought to establish control. Disproportionate force (on the part of Government forces and indiscriminate targeting on the part of both Government and rebel/opposition forces) became rampart.

Distinction as a principle of war under international law does not permit of indiscriminate attacks. It requires belligerents to, at all time and in all circumstances distinguish between lawful and nonlawful targets in their operations [26]. In every armed conflict, be it international or non-international, civilians (those who do not take active part in hostilities) are by default not lawful military targets except where they violate their civilian status by acting as human shields to the enemy [27]. Notwithstanding, they can only become lawful targets after effluxion of reasonable time after warning by a party [28]. Direct targeting of civilians and civilians' support facilities during armed conflict is prohibited for being against known rules of engagement in any armed conflict, and therefore not only morally condemnable but more seriously, a violation of international law with penal consequences [29].

\section{Abductions of Civilians}

Cases of abductions in the Syrian conflict, has been widespread and systematic [ 30 ]. Civilians,

\footnotetext{
${ }^{24}$ Ferris, etal, (n6) 8.

${ }^{25}$ Ibid, 9.

${ }^{26}$ AP I, article 51 paragraph 2, AP II, article 13 paragraph 2.

${ }^{27}$ Y Sandoz, et al, Commentary on the Additional Protocols of $8^{\text {th }}$ June 1977 to the Geneva Conventions of $12^{\text {th }}$ August1949 (ICRC 1987) paragraph 1944.

${ }^{28}$ D J Hessel, 'The Pen and the Sword: International Humanitarian Law Protections for Journalism', [2016] (14:415) The Yale Journal of International Law 420.

${ }^{29}$ See Article 8 (2) (i) which criminalizes intentionally directing of attacks against the civilian population as such or against individual civilians not taking direct part in hostilities.

${ }^{30}$ It is used as an instrument of terror against the civilian population by both pro-regime forces and opposition
}

especially women are used as puns in the hands of their abductors while the male victims are most often than not executed. In very few situations they are forcefully conscripted as combatants or fighters (depending on who their captors are); while their female counterparts are used as sex tools.

Apart from sexual violence, abducted women in Syria are used by their abductors as baits against the enemy forces. It is reported that regime forces do pay as high as 5000 Syrian lira to their agents for each woman brought to them [31]. Cases of women being forced by regime forces to identify their prospective victims abound. Abductees are also induced by their abductors to provide information about their enemies, and sometimes to negotiation for the release of a prisoner with the other party [32]. Information about pro-regime members or FSA elements as the case may be could lead to the release of the victim [33].

Abducted women in Syria are subjected to odious and despicable treatment which suggests the fact of the near total absence of respect for their dignity and honour [34]. Government forces use them to seduce FSA elements in order to establish their locations for the purpose of launching attacks. Any woman who proves uncooperative with her abductors risked the abduction of another member of her family [35].

As stated above, the changing dynamics of the conflict keep defining and directing the modus of operations (in and outside the war zone) by the parties and their allied militia groups. Having largely turned into ethnic, religious and sectarian in nature, the pattern of attacks and abductions are dictated by these closely related but disparate ideological tenets which predominantly define the fundamental objectives of the war. A Syrian woman recounted how one of her two Alawite Shia family neighbours was abducted with her

armed groups in the ongoing conflict in Syria. This act/crime is punishable by international law. In Prosecutor v. Bagosora, ICTR-98-41-T, Judgment and Sentence, 18 December 2008, Bagosora was convicted on several charges, including the charge of rape as crime against humanity committed as part of a wide spread and systematic attack on ethnic and political grounds.

${ }^{31}$ FIDH: Violence against Women in Syria: Breaking the Silence; being a briefing paper based on an FIDH assessment mission in Jordan, December 2012, 15. Available at: <http://wwww.fidh.org/.../pdf/sy...> Accessed on 5/1/2021.

${ }^{32}$ Ibid.

${ }^{33}$ Ibid.

${ }^{34} \mathrm{AP}$ I, articles 75 paragraph 2(b), 76 paragraph 1 and AP II, article 4 paragraph 2(e).

${ }^{35} \mathrm{FIDH},(\mathrm{n} 30) 15$. 
Shaba Sampson., Sch Int J Law Crime Justice, Apr, 2021; 4(4): 198-204

daughter by the FSA only to be traded for a Sunni female hostage with the regime forces [36].

\section{Sexual Assault/Violence}

Sexual assaults/violence is phenomenal is internal conflicts. It has assumed a terrible dimension and is increasingly a disturbing feature of the civil war in Syria. Women, men and children have become victims of this morally debased and heinous crime as is being perpetrated by both pro-regime and opposition armed groups [37]. It is widespread and systematic in style, thereby aggravating the already existing cycle of violence the civilian population, particularly women are already faced with [38]. According to the Special Representative of the Secretary General on Sexual Violence in Conflict, Zainab Hawa Bangura, "the widespread and systematic nature of assault and rape meet the threshold of war crimes and crimes against humanity" [39].

Most allegations of rape and other forms of sexual violence perpetrated by pro-regime forces took place during house searches, at checkpoints and in detention camps [40]. Contrary to the order of nature, decency and morality, women are assaulted and raped in public and sometime in full glare of family members [41]. Sexually abusive activities by the pro-regime forces went so high to the point that family members were forced to commit incest at gun point.

Doctors and psychologists from the Association of Syria Bright Future, working with Syrian women refugees, told members of the International Federation of Human Rights (herein FIDH) the story of a Syrian girl whose brother was forced to rape [42]. It was also reported how women detained in pro-regime camps were injected with sedatives to make them weak and unable to resist sexual assaults [43].

Elements of the opposition armed groups, the Free Syrian Army and allied groups are not left out in this outrage against women and the girl child. A Syrian man told FIDH how a young and pretty girl was abducted by elements of the FSA, raped and shot dead [44].

\footnotetext{
${ }^{36}$ Ibid, 16.

${ }^{37}$ Ibid, 10 .

${ }^{38}$ Ibid.
}

${ }^{39}$ Ibid, 11. Zainab Hawa Bangura was the Special Representative of the Secretary General on Sexual Violence in Conflict. See Article 8 (2) (b) (xxii) makes it a war crime and a crime against humanity. See also Prosecutor v. Bagosora, (supra).

${ }^{40}$ FIDH, (n30) 11.

${ }^{41}$ Ibid.

${ }^{42}$ Ibid, 12.

${ }^{43}$ Ibid.

${ }^{44}$ Ibid, 13.
Information about rape and sexual assaults in Syria is scanty due to religious beliefs, as well as cultural and social factors. Conservative cultural and religious norms forbid Syrian women and girls from talking freely and openly about intimate and private issues such as sexual violence and other forms of violence against women [45].

Victims of gender-based (sexual) violence in Syria are socially abhorred. They are subjected to dehumanizing stigmatization and poignantly repulsive treatment orchestrated by culture and religion. Women in Syria would as a result prefer to die in silence than open up because of the shame, rejection and other repugnant societal torments rape victims go through. Sadly, those who cannot stand the scornful reproach and contempt end up committing suicide [46].

In order to avoid humiliating treatment from members of the society, Syrian women and girls stay away from medical help and psycho-social services even where they exist. Some died in the actual course of sexual violence or later as a result of sexually related diseases like HIV/AIDs while others live traumatized for the rest of their lives without opening up.

\section{Recruitment of Children as Combatant/Fighters}

In almost all cases of asymmetric conflicts, the non-government armed group(s) had almost always resorted to recruitment of children to shore-up their personnel. Just as in the Iraq and south Sudan crises, the opposition armed groups and associated militias in the Syrian conflict are culprits. This cannot be far from being true when considered against the backdrop of the spate of abduction of people below the age of eighteen. Confirming this grave violation of children's right, the Commission of Inquiry on the Syrian Arab Republic (found and reported in August 2013) that Kurdish armed groups have recruited and used children in hostilities [47].

Earlier, the Commission of Inquiry had reported the involvement of the anti-government armed groups in the recruitment and use of children as child soldiers [48]. As in the case of rape and other forms of sexual assaults in which conservative religious, cultural and social beliefs would not permit women in Syria to open up on which accounted for the few reported incidents, there are limited verifiable incidences of child

\footnotetext{
${ }^{45}$ For instance, Doctors from the Association of Syria's Bright Future explained that, 'we do not find rape cases because of the prevailing culture and the refusal to talk publicly about these topics.'

${ }^{46}$ One sad incident is that of the rape of a young woman in Damascus who later committed suicide. See FIDH, (n30) 14.

${ }^{47}$ Ferris, etal, (n6) 7

${ }^{48}$ Ibid.
} 
Shaba Sampson., Sch Int J Law Crime Justice, Apr, 2021; 4(4): 198-204

recruitments. It is so because social and humanitarian aid providers, apart from the prohibitive high risk involved, are deliberately not allow access to conflict areas.

Both the Law of Geneva [49] and the Convention on the Rights of the Child [50] prohibit the recruitment and use of children in hostilities. Although the first Optional Protocol to the Child Rights' Convention [51 ] allows voluntary recruitment of children who have attained 15 years of age but below eighteen, it is however, contingent upon the fulfilment of certain conditions which appear to be in favour of the government party to a conflict.

In recruiting under $18 \mathrm{~s}$, minimum safeguards must be in place to ensure that: the recruitment is genuinely voluntary; is carried out with informed consent of the person's parents or legal guardian; such persons are fully informed of the duties involved in such military service; and that such persons provide reliable proof of age prior to acceptance into national military service [52]. In fact, article 4 of the Optional Protocol out-rightly bars opposition groups from recruiting children under whatever circumstances and age [53]. Similarly, forceful recruitment of children of any age into the State armed forces is considered gross violation of international law which attracts sanctions [54], with the exception of recruitment of those who had attained age fifteen but below eighteen who voluntarily offered their self to be recruited.

In any case, the critical consideration is that an eighteen year old and below is considered not old enough to understand the nature of military service; and informed decision by parents or guardians in conflict situation that is devoid of undue influence is hardly possible. Although the first Protocol to the Child's right Convention allows recruitment by State party of children above fifteen but below eighteen on their own 'volition', the foregoing can however, vitiate the quality of such decisions.

Accountability for crimes committed during armed conflicts are seldom emphasized and hardly pursued with the seriousness it deserves. Blanket

\footnotetext{
${ }^{49}$ A.P I Article 77(2) and A.P II Article 4(3) (c).

${ }^{50}$ CRC Article 38.

${ }^{51} 2000$ Optional Protocol to the Convention on the Rights of the Child on Involvement of Children in Armed Conflict.

${ }^{52}$ First Optional Protocol (2000) to the Convention on the Right of the Child 2000, article 3 paragraph 3.

${ }^{53}$ Ibid, article 4 paragraph 1 . It states that, "Armed groups that are distinct from the armed forces of a State should not, under any circumstances, recruit or use in hostilities persons under the age of 18 years".

${ }^{54}$ See The Rome Statute, article 2 (xxvi).
}

amnesty tactics which has been employed by opposition groups as a condition for laying down arms and restoration of peace and order [55] is responsible for this failure. Unfortunately therefore, the chances of victims of war crimes getting justice at the end of the day becomes very slim notwithstanding their rights under the relevant instruments.

\section{Humanitarian Crisis}

Gross violation of international human rights and international humanitarian law by both government forces and dissident armed group(s) in almost all internal armed conflicts is a major cause of internal displacement [56]. Ordinarily, how long an armed conflict lasts does not actually define and determine the level and pattern of violation and abuse of the rights of victims by the parties to the conflict. However, it holds true that a prolonged armed conflict would usually lead to far more unwholesome practices as the days go by with the implication for a worsening conduct of the actors which impacts negatively on those caught in its web.

Exemplarily as at September, 2013 it was estimated that 4.2-5.1 million people had been internally displaced as a result of the crisis in Syria [57]. The figures keep rising. The number of Syrians in dire need of humanitarian assistance (including those displaced) in the form of shelter, food, medic, etcetera has risen astronomically. This is not surprising given the sectarian and ethnic nature of the crisis and the radical and militarized approach by the parties to the conflict which has taken its toll on and, has in fact, weaken the Syrian economy and its infrastructure base.

It is no longer news that Syria is almost a failed State with a collapsed economy [58] and a badly fractured infrastructure as a result of the prolonged war in Syria. What this means is that public and social services have broken down and at very low ebb where they still exist. Efforts by humanitarian bodies and aid workers suffer frustration and sometime outright ban by party(s) to the conflict from accessing areas that the victims are perceived supporters of the opponent.

Several displaced Syrians in camps and outside camps are in acute need of humanitarian assistance. Blockade tactics by government/regime forces has aggravated the humanitarian situation in Syria. For example, access points to Dara, Baniyas, Homs, Ar Rastan and the suburbs of Damascus (considered as strongholds of the opposition) were at some time completely cordon off with tanks and armoured

\footnotetext{
${ }^{55}$ The Convention however provides exceptions in paragraph 3 of Article 38 for State Parties only.

${ }^{56}$ Ferris, etal, (n6) 6.

${ }^{57}$ Ibid, 10.

${ }^{58}$ Ibid, 9.
} 
Shaba Sampson., Sch Int J Law Crime Justice, Apr, 2021; 4(4): 198-204

vehicles by regime forces to prevent the delivery of food and medical supplies [59]. Starvation strategy (against the civilian population) during armed conflict by any party to the conflict is a strong weapon, and if not checked could defeat public opinion against the opponent with attendant loss of confidence which impacts the morale of the combatants or fighters negatively. In as much as it may work for the party involved, it is however, a war crime and crime against humanity under international law [60].

\section{CONCLUSION}

Syria seems stocked in a military quagmire. Over a decade on, Syria has been suffocating under the effect of military operations which got complicated by the changing dynamics of the war along three trajectories. Firstly, the push for the overthrow of Assad's regime (this however was not part of the agitation at the initial time); secondly, the internationally and regionally sponsored armed groups with the intent to break up Syria for their own interest; and thirdly, the 'coalition' against Islamist jihadist groups. It is arguably believed that, if not for the 'support' of Russia and China in blocking initial sanctions against the Assad led administration, Syria would have sank long ago economically.
It is doubtful whether the international community really mean well for the people of Syria when viewed against the backdrop of the several opportunities the global body have trivialized in its so called efforts to abate the crisis couple with the role of some key players in the weaponization of armed groups in Syria.

While the resilience of the people of Syria is highly commendable, it is important to state the obvious imperative that, it is up to Syria to defend its territorial integrity. It is however important that they first of all realize the magnitude of the devastation the war has brought upon them as a people. They should also be able to clearly understand what exactly they want, that is peace, and chart the path to achieve it otherwise posterity will never forgive them.

Forgiveness, trust and the need to see themselves as one people with a common fate and future form the building blocks to their Eldorado. In the mean, it is important to emphasize that the non-fighting part of the civilian population should be spared the direct attacks and the several abuses the Syrian civil war had been characterized with. One of the ways to compel belligerents (combatants and fighters) to exhibit conducts that are in consonance with the law of armed conflicts is, first to educate all concerned on the contents of the Geneva Conventions of 1949 and their 1977 Protocols and, second and most important, to bring individuals who have committed acts of war crimes and crimes against humanity to face justice.

\footnotetext{
${ }^{59} \mathrm{~L}$ Arimatsu and M Choudhury, op cit., n.137 p 8. For example, in Madaya village of 30,000 people which is about 50 kilometers away from Damascus was under siege by regime forces. Starvation forced the inhabitants to anything including grasses for survival.

${ }^{60}$ A.P I Article 54(1 and 2) and A.P II Article 14 both prohibits destruction of facilities and items that are indispensable to the survival of civilians. The Statute of ICC Article 8(2) (b) prohibits and makes a war crime the use of starvation of civilians as a method of warfare by depriving them of objects indispensable to their survival, including willfully impeding relief supplies.
} 